Валентина М. Илић

УДК $371.3:: 81 ’ 373$

Универзитет у Београду

Стручни рад

10.19090/mv.2016.7.137-155

Филолошки факултет - Катедра за српски језик са јужнословенским језицима Београд

vli1@ymail.com

\title{
МЕТОДИЧКИ ПРИСТУП ЕТИМОЛОГИЈИ НА ЧАСОВИМА ЛИНГВИСТИЧКЕ СЕКЦИЈЕ У СРЕДЊОЈ ШКОЛИ
}

\begin{abstract}
АПСТРАКТ
У раду је представљен методички приступ уводу у етимологију. Имајући у виду обим (три наставна часа), намену (обрада на часовима лингвистичке секције у трећем разреду средње школе), као и слабу заступљеност дијахронијске перспективе науци о језику у наставним програмима, овај методички триптих осмишљен је зарад упознавања с основним постулатима етимолошке науке. Ученицима се - применом комуникативног приступа - (а) представља етимологија као научна дисциплина, (б) ђаци се оспособљавају за коришћење етимолошких речника, (в) а на примерима из Вукове збирке Српских народних пословица детаљно се анализирају најфреквентније именице (кућа, Бог); уз то, организацијом методичког модела остварује се корелација са садржајима из области лексикологије и с наставом књижевности, те подстиче дугорочна мотивација за ширење знања из опште културе.
\end{abstract}

Кључне речи: етимологија, језичка сродност, порекло речи, народне пословице, настава српског језика.

\section{METHODOLOGICAL APPROACH TO ETYMOLOGY IN TEACHING LINGUISTIC ELECTIVE COURSE IN A HIGH SCHOOL}

\begin{abstract}
This paper presents a methodological approach to the introduction in etymology. Considering the volume (three teaching classes), purpose (processing in the linguistic elective course in the third year of high school), as well as poor representation of diachronic perspective on language studies in the curricula, this methodical triptych is designed in
\end{abstract}


order to introduce the basic postulates of etymological science. Students are — by using the communicative approach — (a) introduced to the etymology as a scientific discipline, (b) trained to use etymological dictionary; (c) on the examples of Vuk's collection of Serbian folk proverbs the most frequent nouns (house, God) are analysed in detail. Besides that, by the organization of methodological model the correlation between the lexicology and teaching liteature is achieved, and the long-term motivation for spreading the knowledge in the general culture is encouraged.

Key words: etymology, language relationship, word origin, folk proverbs, Serbian language teaching.

\section{1. УВОД}

1.1. За разлику од већине других области науке о језику, које се на часовима српског језика изучавају током основношколског и средњошколског образовања, етимологија је наука о којој данашњи ученици знају веома мало, јер се неретко о њеном подручју интересовања и постигнућима говори само на часовима српског језика у филолошким гимназијама, а понекад и у оквиру додатне наставе матерњег језика у гимназијама општег или друштвено-језичког смера. Поред тога, ова област веома мало је заступљена у високошколским наставним програмима, те нећемо много погрешити ако кажемо да етимологија данас пуним плућима живи и развија се једино при Етимолошком одсеку Института за српски језик САНУ. С обзиром на наведене чињенице, добра прилика за увођење етимологије у наставу, а тиме и за формирање свести о њеном значају, јесу часови лингвистичке секције, који окупљају посебно мотивисане ученике спремне да знања о свом језику прошире и, сходно природи ове области, продубе; речју - да уз наставникову помоћ и властиту интелектуалну активност сегну у далеку прошлост и открију невидљиве нити којима су, на први поглед једноставне и аутономне, речи савременог језика повезане.

1.2. Приликом структурисања овог методичког модела, водили смо рачуна о томе да сва научна знања буду адекватно и приступачно представљена. Зато смо, уз садејство низа методичких радњи, које за циљ имају што ефективније преношење и усвајање језичког инпута, у фокус интересовања поставили пажљиво одабране теме и појединости, једнако занимљиве и корисне за даље развијање ученичких интересовања, као и за обликовање наставниковог приступа овом градиву. 
1.3. Образовни цчиљеви представљених часова, планираних за реализацију у оквиру лингвистичке секције, подразумевају усвајање основних постулата етимологије као посебне научне дисциплине. Упознајући ученике са њеним историјским развојем и предметом истраживања, ову релативно младу науку младима ваља приближити најпре преко сазнања да - поред лексикологије, која се такође бави речима (лексемама) у најширем смислу - постоји наука у чијем се истраживању порекла речи синхронија и дијахронија сусрећу и стапају. Одшкринувши врата ове области, ученици ће проширити своја знања из историје језика, подсетити се генетских класификација и разумети порекло језичких сродности на којима су оформљене породице језика. На примерима из усмене књижевности ђаци ће уочавати речи које припадају основном лексичком фонду и сазнавати генезу њихових значења, а увидеће, такође, и утицај контекста на савремену семантику. Сусрет с етимолошким речницима омогућиће јасније разликовање намене и облика њихове употребе у односу на речнике страних речи.

Васпитни цицьеви односе се, пре свега, на развој свести о генетској повезаности језика̄, јачање интересовања и потребе за учењем страних језика, чије познавање доприноси и темељнијем познавању матерњег. Овакав приступ такође доприноси формирању правилног става према речима страног порекла у српском језику, које, разуме се, није могуће, а ни потребно у потпуности потиснути, али их свакако треба рационално користити у складу с контекстом, стилом и потребама учесника у комуникацији. Пошто је природа етимологије таква да подразумева познавање бројних нејезичких чинилаца, ученици се васпитавају да теже „енциклопедијском духу“, тј. познавању читавог сплета бројних, али веома интересантних чињеница из историје, географије, религије, филозофије, културологије, демографије, али и других наука, чиме се обезбеђује широка основа за корелацију с различитим предметима, а такође и висок степен индивидуализације наставе.

Функциионални ц̧иљеви овог блока часова тичу се стицања практичних умења и знања применљивих у даљем образовању; посебно се развијају моћи запажања (корена речи, суфикса, творбено-семантичких група), упоређивања и аналошког закључивања. Ученици се оспособљавају да ослушкују свој језик и детаљније истражују генезу форме и значења речи које припадају основном лексичком фонду. Затим, пошто прошире своја знања о етимолошким речницима, ђаци постају кадри да их користе приликом истраживања порекла различитих речи. Будући да ће након ових часова ученици бити мотивисани да откривају нове етимолошке везе, то ће утицати на развој радних навика и истраживачког духа, стога далекосежнији циљеви укључују стварање навике коришћења речника зарад провере властитог 
језичког осећања, али и потребу за читањем и праћењем шире литературе, у чему наставник треба да им пружи очекивани подстицај и помоћ.

1.4. Корпус из којег смо ексцерпирали примере намењене презентовању резултата етимолошких испитивања на часовима лингвистичке секције јесу кратке форме усмене књижевности - народне пословице. Поред тога што - као „сажете завештајне формулације искуства“- имају изражену васпитну вредност, пословице су погодне за етимолошка испитивања због свог лексичког састава. Наиме, добар део речи употребљених у нашим народним пословицама творбено је неразложив. Са синхронијског становишта, то су просте речи, а у њихову дијахронијску семантику готово да не залазимо јер их сматрамо крајњом, односно базичном инстанцом у лексици матерњег језика. ${ }^{1}$

2. ПРВИ НАСТАВНИ ЧАС: ЈЕЗИЧКА СРОДНОСТ И ЈЕЗИЧКЕ ПОРОДИЦЕ. ЕТИМОЛОГИЈА КАО НАУЧНА ДИСЦИПЛИНА - ПОСТАНАК И РАЗВОЈ. ЕТИМОЛОШКИ РЕЧНИЦИ.

2.1. На првом наставном часу ученике усмеравамо на активирање постојећих знања о историјском развоју језика, на појмове језичка сродност и језичка породица. Након понављања и проширивања знања о стаблу индоевропских језика, ученици се уводе у њима дотад сасвим непознату област - етимологију, научну дисциплину која се бави пореклом речи. На овом часу ђаци први пут долазе у контакт с етимолошким речницима, упознају њихову сврху и уче како да користе Etimologijski rječnik Петра Скока, као и Етимолошки речник који се израђује у Институту за српски језик САНУ.

2.2. Према једној од класификација језика̄, која се назива генетском, језици се деле на језичке породище, односно на скупине језика који имају заједничко порекло и које повезује појам сродности. Језичка сродност најпре се уочава у заједничким коренима речи, али и у сличном гласовном склопу, те у граматичкој структури; Р. Бугарски то објашњава овако: „Када су сличности у структури и речнику двају или више језика тако велике и систематске да се не могу објаснити случајношћу, позајмљивањем или неким

1 Њихова ознака у нашој свести изједначена је са означеним без остатка. Обично се никада не питамо, на пример, зашто појам/реалију „кућа“ именујемо речју одређеног гласовног склопа: к-у-ћ-а. Када се над тим замислимо, увиђамо да је апстрактност овог низа гласова/ графема за нас ишчезла већ приликом усвајања језика, када смо одређени гласовни склоп везали за конкретан појам. 
нужним општим обележјима свих језика [...], лингвисти утврђују да су ти језици генетски сродни, што значи да воде порекло од заједничког претка“ (Бугарски ${ }^{4}$ 2008: 46). Тај прајезик реконструише се методама историјске и упоредне лингвистике, и то на основу података које пружају писани документи и савремени језици.

Науци је до данас познато око двадесет језичких породица које се даље деле на гране; с друге стране, неке језичке породице могу бити у сродству, па тада говоримо о језичким родовима. Најчешћи узрок који доводи до такве језичке дивергенције јесу сеобе становништва, након којих се један језик дели на дијалекте; уколико су ти дијалекти просторно и временски удаљени, могу се толико диференцирати да постану међусобно неразумљиви. Таква је судбина задесила индоевропску језичку заједницу, чији су потомци током неколико миленијума заузели огромна пространства између три океана - Индијског, Атлантског и Тихог.

2.3. Већ на основу овако постављеног уводног дела часа, постаје јасно да су за посматрање и изучавање генезе речи неопходна знања историје и историјске лингвистике. У овој фази часа путем видео-бима треба предочити индоевропско језичко стабло, јер помоћу таквог ликовног (и метафоричког) приказа ученици боље разумеју појам језичке сродности, што доприноси већој ефикасности усвајања и трајности упамћивања представљеног градива. Даљим дијалогом долази се до примера сродних језика (словенска, германска, романска група језика), а посебна пажња поклања се словенским језицима - источној, западној и јужној грани словенских језика, чији је заједнички предак прасловенски језик. На основу познавања историје језика, ученици одговарају на питања о постанку савременог српског језика: Који је први књижевни језик Словена? Које су његове редакиије? Где се употребљавао? Шта је диглосија? Када народни језик званично улази у книжевност? и сл.

На овај начин већ на самом почетку часа ученике - преко њима познатих појмова - упућујемо у језичку прошлост и мотивишемо их да сазнају нешто више о једној дијахронијској дисциплини која доприноси темељнијем упознавању матерњег језика.

2.4. Као грана лингвистике, етимологија је зачета још у античко доба. ${ }^{2}$ Њено име потиче од грчке именице etymologia, која означава „право,

2 Поред других извора, веома корисне и релевантне податке о етимологији као научној дисциплини ученици могу добити слушајући предавање др Марте Бјелетић „Етимологија као лингвистичка дисциплина и рад на етимолошком речнику“, одржано 17. децембра 2014. године у Научном клубу Центра за промоцију науке у Београду, које је доступно на следећој 
истинско значење речи!“. У то време етимологија није била наука у правом смислу речи - каква је данас - већ ce, у начелу, бавила питањем да ли су речи у природној вези са стварима на које се односе, или су плод људске конвенције. Као модерна наука, етимологија се почела конституисати тек почетком XIX века са појавом упоредне лингвистике. Од тада је прошла кроз неколико фаза: 1) оријентација на спољашњу (формалну) сличност речи које се пореде, 2) оријентација на фонетику и апсолутизација гласовних законитости, 3) усмереност на морфонологију и творбу речи (тако се са коренске етимологије прешло на етимологију конкретних речи) и 4) оријентација на семантику.

2.4.1. Етимолошки поступак укључује познавање гласовних законитости и промена, творбе речи, семантике, као и знања везана за бројне нејезичке чиниоце. Дакле, за етимолошко тумачење одређене речи није довољно утврдити њен корен, него и време настанка, њен првобитни облик и изворно значење (а потом и његов даљи развитак). Како истиче Б. Сикимић, циљ истраживања савремене етимологије није само „одвојени, изоловани етимон (корен речи), већ је то сложено одређивање координата, које одређују где се реч, схваћена као јединство форме и значења, укључује у одговарајуће семантичке и формалне системе и подсистеме“ (Сикимић 1996: 9). Тако, на пример, за именицу пост није довољно рећи да потиче од готске именице fasto која значи држање, него се мора објаснити да глагол fastan, од којег је наведена именица изведена, значи држати (се), придржавати се (правила, прописа), што ће рећи: придржавати се правила о исхрани. Управо се по оваквим објашњењима етимолошки речници разликују од речника страних речи, који само наводе од које је стране речи настала домаћа (Влајић-Поповић 2013: 14).

2.5. Након уводних напомена, ученици се обавештавају о основним теоријским постулатима етимологије као научне дисциплине и сазнају од када се човечанство интересује за порекло речи. На примеру из свакодневног језика треба им приближити етимолошки поступак, што ће их подстаћи да размишљају и о пореклу и развоју других речи. При томе се мотивацијски механизам ослања и на богатство и занимљивост нејезичких фактора укључених у етимолошку анализу, будући да подаци који се сазнају из етимолошких речника могу потврдити и употпунити знања ученика не само о језику, већ и о свету који их окружује. Тако се откривају нове везе међу речима, нова семантичка гнезда, као и везе међу страним језицима,

интернет адреси https://www.youtube.com/watch?v=bG6rjGwx8GM; 15.3.2015. 
ближим или даљим прецима, јер постојања таквих скривених спона често постајемо свесни тек након етимолошких објашњења. Након теоријских објашњења и иницијалних примера, ученике упознајемо са релевантним етимолошким речницима и њиховом структуром.

2.6. Почетак модерне словенске етимолошке лексикографије означио је Миклошичев Етимолошки речник словенских језика (1886), а данас најзначајнији општи Етимолошки речник словенских језика, који реконструише лексику прасловенског језика, објављује се у Москви од 1974. године. Зато је умесно истаћи запажање Р. Драгићевић, која напомиње да „Има аутора који етимологију називају лексикографском дисциплином, чиме истичу да свој највећи допринос науци о језику етимологија постиже у изради етимолошких речника“" (Драгићевић² 2010: 19).

2.6.1. Када је реч о српским етимолошким речницима, свакако треба нагласити да је „српскохрватски језик релативно касно у односу на многе индоевропске језике добио свој први етимолошки речник“ (Сикимић 1996: 8). У питању је Etimologijski rječnik hrvatskoga ili srpskoga jezika (1971-1974) Петра Скока, за који је аутор грађу сакупљао четрдесет година. Будући да П. Скок за собом није оставио програмске чланке којима би нам били приближени његови методолошки путеви, наши етимолози данас се у свом раду ослањају на искуства својих претходника и савременика који се баве другим словенским језицима, а такође се угледају и на шире етимолошке пројекте. Скоков речник састоји се од три тома и четвртог - Казала, у коме су пописане све обрађене речи; поред тих речи стоји упутница под којом се одредницом жељена реч налази у речнику, што умногоме олакшава употребу овог речника. У овом речнику се, дакле, речи не бележе линеарно, једна за другом, већ су обрађене у гнездима: тако су - у оквиру истог речничког чланка - обрађене све речи које везује заједничко порекло.

2.6.2. Етимолошки речник српског језика израђује се у Институту за српски језик САНУ. Његову израду покренуо је 1983. године академик Павле Ивић, а до сада су објављене три свеске (А-АШ; БА-БД; БЕ-БЈ), које обухватају око 1900 одредница. Аутори овог речника су М. Бјелетић, J. Влајић-Поповић, С. Петровић и Александар Лома - који је истовремено и уредник. Речник је замишљен првенствено као допуна Скоковом речнику, међутим, прерастао је у потпуно нови речник - тезаурус. Поменути аутори поред овог великог речника израђују и једнотомни Етимолошки речник српског језика, који ће, сматрају, бити велика потпора изради вишетомника. У овом речнику се у оквиру исте одреднице обрађују само речи које су синхронијски и творбено повезане, док се дијахронијски повезане речи обрађују као посебне лексеме. 
2.7. Даљи рад на часу лингвистичке секције подразумева сусрет с етимолошким речницима - П. Скока и свескама Етимолошког речника српског језика, те након кратког представљања њихових основних карактеристика, примере употребе приказујемо путем видео-бима. Ученици се најпре оспособљавају за коришћење Казала. Закључују да је, на пример, именица туга настала од тегнути, и то превојем вокала, а ново сазнање код њих ствара потребу за сличним открићима. Потом следи представљање речничког чланка. Ђаци треба сами да увиде како етимолошка анализа подразумева примену одређених правила, а уз наставникову помоћ, на конкретном примеру, они их прецизирају; при томе уочавају да се, после датирања речи, утврђује старији облик лексеме која је предмет интересовања, наводе се одговарајуће речи у другим сродним језицима, као и изведенице које потврђују стабилан статус лексеме у језику. Ова правила ученици запажају и спознају листањем и читањем етимолошког речника. На крају се дају закључне напомене о развитку форме и значења кроз историју, као и о заједничким коренима речи у сродним језицима, те о семантичким везама, њиховом просторном и временском сезању.

\section{3. ДРУГИ НАСТАВНИ ЧАС: ЕТИМОЛОГИЈА НАЈФРЕКВЕНТНИЈИХ ИМЕНИЦА У СРПСКИМ НАРОДНИМ ПОСЛОВИЦАМА}

3.1. На овом часу ученици најпре обнављају знања из лексикологије, а пажња се фокусира на значење (речи) као категорију која није окамењена, већ се може мењати и развијати, чак и на синхронијском плану. Потом их уводимо у историју значења речи, како би се на конкретним примерима показао ток промене значења именица, њихово порекло, прва потврда и др. Будући да примере узимамо из народних пословица у којима се огледа живи народни израз, они стичу потребу да сами проналазе објашњења за поједине лексеме, што је добар подстрек за даљи индивидуални рад.

3.2. Зарад утврђивања лексичке окоснице нашег методичког приступа, одабрани паремиолошки корпус подвргли смо фреквенцијском испитивању и тако дошли до десет именица које се у српским народним пословицама најчешће јављају. Захваљујући издању Вукових народних пословица с регистром кључних речи може се без великих тешкоћа - увидом у регистар који је сачинио М. Шћепановић - утврдити које се лексеме у њима најчешће јављају: то су оне уз које у регистру стоји највише бројева који представљају редне бројеве пословица у збирци. Њиховим пребројавањем долазимо до апсолутне фреквенције, односно тачног броја јављања одређене лексеме у 
пословицама. Будући да је у питању специфичан језички супстрат којим је изражено свеколико народно искуство, везано за безмало све области живота, сви су изгледи да у њему најзаступљеније лексеме репрезентују појмове од виталног значаја за животну филозофију и морални кодекс нашег народа. Истовремено, оне улазе у језгрени део лексике нашег језика и заједнички вокабулар носилаца српског језика као матерњег, због чега заслужују посебну пажњу. Све су ово ваљани разлози због којих смо те лексеме одабрали и уврстили их у најужи корпус на коме ће ученицима бити представљене (у оквиру часова лингвистичке секције посвећених стицању знања из области етимологије).

Наша анализа је показала да у народним пословицама убедљиво највећу фреквенцију има властита/апстрактна именица Бог, док се од заједничких/ конкретних именица најчешће јавља именица кућа, потом лексема човек и именице којима се именују делови његовог тела (глава, око, рука, нога), а на зачељу ове проминентне групе налазе се именице вода, пас и коњ.

Овакви резултати потврђују теорију о антропоцентричности језика. Поред тога, редослед најфреквентнијих лексема у српским народним пословицама указује на значај човековог ослонца у оностраном и о разумевању Бога као духовног уточишта. На другом месту је физичко уточиште - кућа/дом, на трећем је са̂м човек (човек; глава, око, рука, нога), потом животодавна материја - вода и, најзад, животиње које су му најближе (nac, коњ). Ови појмови, можемо рећи, јесу нека врста појмовних примитива наше културе и језика.

Фреквентност поменутих лексема представљамо следећом табелом која за сваку од десет најзаступљенијих речи доноси број пословица у којима је употребљена:

\begin{tabular}{|c|c|c|c|c|c|c|c|c|c|}
\hline Бог/божији & кућа/дом & човек & глава & око & рука & нога & вода & пас & коњ \\
\hline 363 & 154 & 149 & 133 & 125 & 85 & 69 & 113 & 111 & 83 \\
\hline
\end{tabular}

3 Примећујемо да именице рука и нога, које представљају делове човековог тела, имају нешто нижу фреквенцију од главе и ока, као и од воде и $n c a$, али их због објективно високог броја пословица у којима се јављају наводимо у табеларном низу уз остале лексеме које означавају делове тела (глава, око).

Пошто се ради о уводном делу (другог) часа, на коме ђаке треба подсетити на флуидност значења у контексту (синхронијски план), овом приликом се не треба превише задржавати на детаљнијем разматрању полисемије, јер су ова знања већ усвојена на часовима редовне наставе, те сада имају функцију сазнајне потке која се надграђује у правцу дијахроније. 
Ученике путем видео-бима обавештавамо о резултатима наше фреквенцијске анализе, истичући важност појмова и реалија репрезентованих овим лексемама, захваљујући чему оне имају посебан статус у лексикону српског језика. На овом и наредном часу лингвистичке секције посебно ћемо се бавити етимологијом двеју најфреквентнијих именица. Најпре ћемо се задржати на заједничкој именици - кyћа, а потом, читав идући час посветићемо властитој/апстрактној и убедљиво најфреквентнијој именици у српским народним пословицама - Богу. На том часу ћемо нешто рећи и о пореклу именице non, будући да је у логичкој вези са именицом Бог, а у пословицама такође се јавља у достатном броју примера.

3.3. Следећи наставни корак подразумева приказивање одабраних народних пословица на видео-биму у којима се јавља лексема чију ћемо етимологију представити. Она припада основном лексичком фонду, што потврђује и велики број пословица у којима је посведочена:

- Ако комшијска кућа гори, пази на своју.

- Ако гости нису бесни, кућа није тесна.

- Далеко му лепа кућа!

- Договор куће не обара.

- Где није жене, онде није ни куће.

- Кад мачка у кући није, онда се мишеви веселе.

Ученицима ваља посебно нагласити да је Вук у својој познатој збирци забележио чак 120 пословица у којима је лексема кућа кључни појам. То показује колико важно место кућно огњиште заузима у човековом животу. Ученици казују и њен синоним - дом, а наставник претходну информацију допуњава следећим податком: именица дом се код Вука јавља у преко 30 пословица, што укупан број примера који се тичу куће / дома битно увећава (укупно их је 154).

Динамику дијалога подстичемо на следећи начин: (а) подсећамо ученике на примере свакодневне употребе ове именице и њених деривата: нпр. зашто се домаћи задатак ради код куће, а кућне послове обавља домаћиия, чиме укључујемо комуникативни приступ настави језика (исп. Вељковић Станковић 2013: 27), а потом их питамо осећају ли какву разлику између ових синонима и тражимо образложење одговора; (б) такође, питамо их да ли знају још неке језике у којима постоји овакво двојство (нем. Haus и Heim, енгл. house и home, шпан. casa и hogar); (в) подстичемо их да размишљају о пореклу и старини речи кућа и дом (која је реч старија?). Тако се еротематским путем подстиче интерес за ново градиво и охрабрује трагање за решењима проблемских ситуација. 
3.4. Данас се реч кућа најчешће употребљава са значењем ,зграда у којој неко живи', док се домом обично сматра ,породично пребивалиште, породично гнездо, завичај'. Дакле, за другу лексему везујемо богату конотацију која укључује топлину, миље и блискост. Многи примери, међутим, показују да ова дистинкција није одувек постојала, па се тако у наведеним пословицама именица кућа употребљава и са значењем дом:

- Ако гости нису бесни, кућа није тесна.

- Док је мој бабо облазио, донде је кући долазио, а сад како пође на пречац, онако и заглави.

- евојке су ископ али част кући. Јер кућу затиру својом удајом, али се с њима опет стеку пријатељи, којима се чоек дичи.

- Ко од двадесет година не зна, а од тридесет нема, тешко кући која га има!

У литератури се наводи да је у старосрпском кућа означавала и ,колибу', док се у Повељи Стефана Уроша из XIII века јавља чак и значење ,радње' (Влајић-Поповић 2013):

- да имь се не узима ... ни медь, ни мука, ни која купља; и куће да имь се не печате, ни оть краља ни оть властель.

3.4.1. Ови подаци, међутим, још увек не доприносе бољем разумевању лексема о којима је реч, па стога морамо заћи у даљу прошлост. Поглед у Скоков етимолошки речник увериће нас да су обе речи веома старе, али је дом знатно старија лексема и потиче из индоевропског језика. Изведена је од индоевропског корена *dem- који има значење ,градити, састављати', а очувала се у словенским језицима, али и у латинском (domus - кућа), литавском (dimstis - двориште, које је ограђено), грчком (domos - градња), староиндијском (damas - градња, кућа). Лексема кућа настала је почетком наше ере у прасловенском језику, а данас постоји само у јужној и источној грани словенских језика, док се у западној не јавља; једино је у српском, македонском и бугарском језику преузимала значење које је до тада имала реч дом, али је није потиснула из употребе (исп. Влајић-Поповић 2013).

3.4.2. Ученицима ће свакако бити врло занимљива и тумачења наших етимолога ${ }^{4}$ којима се осветљава порекло и развитак значења речи кућа у

4 Бројни су радови домаћих аутора који се баве етимолошким испитивањима. Ученицима можемо, за почетак, препоручити књигу Речите речи др Јасне Влајић-Поповић, која је написана научно-популарним стилом и прилагођена разним узрастима: од средњошколског до универзитетског. За потребе овог рада користили смо је као драгоцен извор. 
сродним језицима. Претпоставља се да је именица кућа настала од именице куm, која је означавала увучени, скривени угао. Подаци из књижевног језика и дијалеката говоре да куm данас значи ,угао (унутрашњи), скровито место, буџак', ,угаони део, крај', ,периферни део неке територије, предео', ,доњи део кошуље, скут'. Нарочито су важна нека значења која долазе из динарских крајева: ,рупа у зиду изнад огњишта у коју се ставља пепео', ,истурени део зида у кући изнад огњишта', јер управо она чувају везу између кута и огњишта, која се задржала и у неким дијалектима других словенских језика. Облик кућа настао је додавањем суфикса -ja на облик куm, а различит лик ове лексеме у другим словенским језицима резултат је друкчијег развоја старог назала о, који је у словенским језицима давао различите континуанте, као и сугласничку групу -mj-, која је у српском дала $\hbar$, у бугарском $щ$, у источнословенским језицима $ч$ (исп. Влајић-Поповић 2013).

3.4.3. Дакле, пошто је кут првобитно означавао ,угао у коме се налази огњиште', кућа је отуда ,просторија у којој се налази куm'. Она је могла означавати једину просторију у којој се живело (археолози и историчари потврђују да су земунице Старих Словена баш тако и изгледале), или пак просторију у којој се налазило огњиште, тј. ,кухиња'. Ово значење се у јужној грани словенских језика уопштило до значења које данас има именица дом, са понеким примерима који чувају везе с огњиштем. Будући конзервативан, српски језик у основној речи кут чува елементе који означавају

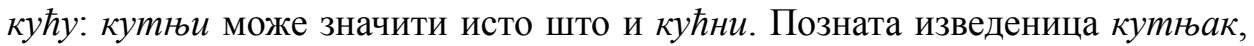
по аналогији са двојношћу значења именице кут (апстрактно - конкретно), такође има два значења: ,велики зуб у углу вилице' и дијалекатско ,човек који зими стално проводи време уз огњиште или пећ' (исп. Влајић-Поповић 2013).

3.4.4. Методичке напомене. Примери народних пословица из грађе потврђују дилему о дистинкцији између куће и дома, након чега се ослањамо на релевантну литературу. Пре него што се упустимо у објашњења порекла речи дом, од ученика очекујемо да наведу лексички еквивалент у латинском језику (domus), чиме се у њиховој свести осветљавају сложеније међујезичке релације, те сами закључују да је у питању индоевропска реч (превазилази словенске размере). (Потом наставник својим објашњењем употпуњује њихова запажања.)

Такође, пре етимолошке анализе речи кућа проблематизујемо питање њене творбене основе и суфикса (-ja) којим је добијена; подстичемо ученике да наведу (контекстуализоване) примере употребе именице кут и њена значења. Ново градиво треба да оснажи ученичку радозналост, нарочито 
када схвате да паралелно с усвајањем знања и упознавањем постигнућа етимолошке науке стичу увид и у многе историјске податке, чињенице из живота Прасловена и Индоевропљана, везане за њихову културу, религију и свакодневицу.

\section{4. ТРЕЋИ НАСТАВНИ ЧАС: ЕТИМОЛОГИЈА ЛЕКСЕМЕ БОГ. О ПОРЕКЛУ ИМЕНИЦЕ ПОП.}

4.1. На овом часу настављамо са представљањем етимологије речи које се јављају у највећем броју наших пословица. Пошто су на претходном часу усвојили етимологију лексеме кућа, на овом часу бавимо се пореклом и семантичком генезом најфреквентније именице у српским народним пословицама - лексемом Бог. Уз њу, обрадићемо и лексему non, за коју смо утврдили такође релативно високу фреквенцију јављања. На тај начин се заокружује најужи тематски скуп појмова (везаних за овоземаљско и онострано) од којих је саздано лексичко језгро српских народних пословица.

4.2. У Etimologijskom rječniku именицу Бог налазимо под одредницом богат, која је придев балтословенског порекла настао од именице бог када је она значила ,земаљско добро, срећу' (онај који поседује земаљска добра = богат). За историју значења именице Бог важна су још два изведена придева - убог и небог, први са префиксом y-, други са негацијом не-, оба општесловенског порекла. Они упућују на чињеницу да је данашња именица бог некада била и придев. Префикс $y$-, који је настао од *v-, унео је значење супротности, па је овај придев, као и разна поименичења од њега настала, имао значење сиромашан, сиромаштво, просјак, итд. За други сложени придев наводи се да је реч „смиловања и саучешћа“; изведенице од њега означавају јадника, сиромаха, итд.

Именица бог (ген. бога) прасловенског је порекла, али без паралела у балтичкој групи језика. Најпре је означавала ,срећу', односно ,земаљско добро', ,робу', на шта упућује црногорски одговор Добра ти срећа на поздрав Помоз бог.

Првобитни придев *bogъ још је у прасловенско доба постао именица која је означавала, божанство које раздељује срећу и земаљска добра по свом нахођењу', а у прилог томе говори паралелни семантички развој у санскриту: bhagas - 1) давалац, господар, 2) богатство.

4.2.1. Према неким изразима из словенске митологије - „beibog, crno(o)bog, daždbog > Dažbog, Dabog, Zao bog“ - може се закључити да је још у прасловенском постојао ирански дуализам: добар и зао бог. Касније 
хришћанство преузима значење доброг бога и ствара се деминутив на -ић: божић $=$ мали бог $>$ Исус, који се узима као назив празника: Божић (Natale Christi), а од којег су настале и бројне изведенице (божићни, божитњи, божитњак, божићница, божићати се, итд.) (исп. Скок 1971).

4.2.2. Потврду о општесловенском карактеру лексеме бог износи и $\mathrm{H}$. Драгин, додајући да ова лексема улази у ред најфреквентнијих у старословенском језику, одакле је ушла у редакцијске писмености, у којима је одржала високу продуктивност. Ауторка на основу својеврсне грађе закључује да највећи број именичких (и придевских) сложеница с богом као првим сложеничким делом упућује на човеков однос према богу (апстрактуми богољубље, богопослушност; богозаборав, богомрскост) или је реч о човеку који је носилац одређене особине, својства или делатности (конкретне именице богомољаи, богоугодник; богохулник, богоотпадник; као и придеви: богоугодан, богоподобан; богохулан, богозабораван). Дакле, у семантици и форми већине сложеница из грађе утемељен је однос човек $\rightarrow$ Бог, који притом може бити позитиван или негативан. Драгин истиче да за поједине лексеме из грађе нема потврда у речницима црквенословенског језика, а једновремено ни речници савременог језика не бележе све потврде. То, како ауторка наводи, сведочи о „продуктивности и отворености“ модела по коме се творе сложенице са богом као првим сложеничким чланом (Драгин 2007).

4.2.3. Породица речи чија је мотивна реч именица бог врло је разграната: богиња, побожан, набожан, божји, божанство, божество, божанствен, боговски (,веома добар'), божански, боговетни (уп. изр. сваки боговетни дан), бокчићи (у народној приповеци), боговати (,називати коме божју помоћ'); важна је изведеница на -јур: божур (божуров, божурак, божурић, божура), јер се ова биљка зове још и перуника - од Перун, како се звало врховно (балто)словенско божанство. Претпоставља се отуда да је бог био словенска замена за Перун.

Када је реч о сложеницама, најпре издвајамо хришћанске преведенице: богослов, богословија, богословље, Богородииа, Богородичин, Богојавsење, богоносаи, богоносан, богомати, богочовек. Има доста сложеница које су синтагматског порекла: богобрат, богосват, богомдан, богомио/богумио, богобојазан, богобојажљив, богорадити, богме, богољубан, богомоља, богомољство.

Најзад, бог се употребљава и у изразима: ако бог да, акобогда (у зн. упитног прил. куда, камо), буди бог с нама, набога, добога, ништа под богом не зна, збогом, и др. (исп. Скок 1971).

4.2.4. Методичке напомене. Овде је важно да ученици увиде везу између именице Бог и придева богат, а такође и да схвате развој значења 
- од земаљьког добра, среће, преко божанства које је раздељује, даваоиа, до данашњег хришћанског Бога. Уз то, указује се на однос између бога у словенској митологији и хришћанству, на основу чега ученици стичу и нејезичка знања која се тичу митологије, односно религије, што их подстиче да се даље информишу о словенској митологији и њеним паралелама са хришћанством. То даље утиче на кумулацију знања из опште културе. Подстичемо их да сами наведу изведенице и сложенице, а онда њихов списак употпуњујемо, те заједно објашњавамо значења непознатих речи. На основу великог броја твореница ученици спознају значај и место ове речи у лексичком систему српског језика.

Након обраде етимологије именице Бог, износимо интересантан податак да је међу српским народним пословицама лексема поп нарочито фреквентна, односно да се јавља у 70 пословица (узимајући у обзир и дублетну форму nona). То потврђује истакнут статус религије у свести говорника српског језика: поред вере (Бог), важан је био и онај који ту веру проповеда (non), па би отуда ваљало (у даљој обради) задржати се и на овој именици.

4.3. После Даничићевог и Вуковог превода Старог и Новог завета синоним именице non - именица свештеник постала је врло учестала, будући да звучи свечано и да се у њој препознаје веза с придевом свети. Међутим, non је у народу старија реч, а то потврђују следеће чињенице: 1) именица свештеник ниједном се не јавља у српским пословицама, 2) именица поп помиње се још у старосрпским текстовима из XIII века, 3) именица поп (одн. попа, одмила) део је српских топонима (Попово поље, Попова река, Попова лука, Попова глава, Поповач, Поповача, Попинач), фитонима (попова капа - ,кандилка', попина погачица -,маслачак', попино прасе) и антропонима (презиме Поповић: у XIV в. у Дечанским хрисовуљама помиње се име Мирослав Поповић, што је значило ,Мирослав, попов син'; сматра се да је то претеча савременог презимена) (исп. Влајић-Поповић 2013).

Као и многе друге именице чији се фонолошки склоп у потпуности уклапа у природу српског језика, па их сматрамо домаћим иако смо их преузели из других језика заједно са појмом који именују, тако и именицу поп осећамо као своју. Наиме, Словени су примајући хришћанство, усвојили и реч non, која вуче корен од грчке речи pappas ( $\pi \alpha \dot{\pi} \pi \alpha \varsigma$ ), отац' (уп. сви хришћани се свештенику обраћају са Оче!). Пошто ова реч постоји у свим словенским језицима, многи научници сматрају немогућим да је она у све њих ушла директно из грчког, па претпостављају њено старонемачко порекло: pfaffe ,поп'. Ово објашњење вероватно важи само у случају западнословенских језика, док су Словени на југу и истоку, који су се покрштавали под грчким утицајем, ову реч примили заједно са осталим црквеним тер- 
минима. Лексему поп прате и речи као што су попадија ,попова жена', од грчког pappadia $(\pi \alpha \pi \pi \alpha \delta i ́ \alpha)$, која је дала и презиме Попадић < *Попадијић, а потом и им. npomonon ,први (главни) поп', насталу од грчког prōtopappas (

У српском језику именица поп мотивисала је глаголе: запопити (се), pacnoпити (ce), као и поповати. Потоњи глагол је - поред денотата ,бити поп, обављати послове попа; држати проповед' - развио још једно значење с негативном нијансом: ,држати придике, замерати подучавањем, закерати' (исп. Влајић-Поповић 2013).

4.4. Методичка напомена. Поред тога што усвајају етимологију речи non, ученици размишљају о српском ономастикону, односно покушавају да уз помоћ наставника дођу до што већег броја речи у којима се ова реч јавља као мотивна, набрајају деривате и њихова значења, а такође увиђају и велики утицај грчког на лексику словенских језика.

\section{5. ЗАКЉУЧНЕ НАПОМЕНЕ}

Будући да ученици трећег разреда средње школе у оквиру редовне наставе стичу знања из лексикологије, она се - као неопходна потка - користе у представљеном наставном моделу предвиђеном за реализацију на часовима лингвистичке секције на којима се заинтересовани ученици упознају са етимологијом. На тај начин постиже се постепена интеграција наставних садржаја - нове сазнајне структуре логично се надограђују на већ стечене. На овим часовима ученици обнављају знања о историјском развоју језика и о језичкој сродности, чиме се усмеравају на дијахронијско посматрање језика, разумевање порекла облика и значења речи. Уводни час посвећен је представљању теоријских поставки етимологије као научне дисциплине и упознавању ученика са основним чињеницама везаним за њен постанак и развој.

Примери предвиђени за детаљнију обраду преузети су из Српских народних пословица, чиме се, поред корелације с књижевношћу, јача мотивација за даље испитивање паремиолошког блага и за откривање културолошки важних чињеница похрањених у језику. Зато се највише пажње поклања језичким и културним етимонима, а детаљно се објашњава историјски развој облика и значења речи кућа и Бог, не занемарујући творенице мотивисане овим лексемама.

Ученици се оспособљавају да стечена знања и вештине примењују у даљем раду - на часовима и самостално - приликом испитивања 
етимологије осталих најфреквентнијих именица из народних пословица до којих смо дошли увидом у регистар кључних појмова. Они се самостално служе етимолошким речницима и литературом испитујући генезу речи и реалија везаних за наш народ и културу; интересују се за дијахронијску лингвистику и откривање нових етимолошких веза. У ширем смислу, похрањују се њихове радне навике и истраживачки дух, а тиме и потреба за испитивањем шире литературе, научним потврдама и провером властитог језичког осећања.

Осим језичких садржаја, нарочито је интересантно и корисно усвајање нејезичких чињеница које се тичу историје, географије, религије и културе Прасловена и Индоевропљана, што треба да подстакне радозналост ученика и допринесе развоју индивидуалне мотивације за самообразовање и развој опште културе. Избор најфреквентнијих лексема у корпусу усклађен је с комуникативним приступом у настави језика, а сва тумачења и чињенице научно су утемељене, чиме показујемо удео и активност Грајсове максиме квалитета у настави матерњег језика (уп. принцип научности), док су број примера и обим обраде усклађени с максимом квантитета. Релевантност наставних садржаја трудили смо се остварити пажљивим одабиром грађе и примера, проблемским питањима и занимљивим експликацијама, при чему смо водили рачуна о томе да све научне чињенице буду интерпретиране у складу с принципима економичности и усклађености с узрастом ученика, чиме би се отворила врата даљим интересовањима ученика за испитивање семантике и историјске подлоге речи присутних у језику свакодневне комуникације, а пре свега за оне у којима се препознају културолошки важни ослонци сачувани у језику.

\section{ЛИТЕРАТУРА}

Бјелетић, М. (2014). Предавање „Етимологија као лингвистичка дисциплина и рад на етимолошком речнику“. [Bjeletić, M. (2014). Predavanje „Etimologija kao lingvistička disciplina i rad na etimološkom rečniku“.] https://www.youtube.com/watch?v=bG6rjGwx8GM), датум посете сајта: 15.3.2015.

Бугарски, Р. ('2008). Увод у општу лингвистику. Београд: Завод за уџбенике. [Bugarski, R. ( $\left.{ }^{4} 2008\right)$. Uvod u opštu lingvistiku. Beograd: Zavod za udžbenike.]

Вељковић Станковић, Д. (2013). Комуникативни приступ у настави српског језика. Београд: Друштво за српски језик и књижевност Србије. 
[Veljković Stanković, D. (2013). Komunikativni pristup u nastavi srpskog jezika. Beograd: Društvo za srpski jezik i književnost Srbije.]

Влајић Поповић, Ј. (2013). Речите речи: од земье до неба. Београд: Завод за уџбенике. [Vlajić Popović, J. (2013). Rečite reči: od zemlje do neba. Beograd: Zavod za udžbenike.]

Драгин, Н. (2007). “Лексеме мотивисане именицом бог у омилијама светог Николаја Српског (синхроно-дијахрони приступ)“. Probleme de filologie slavă 15: 521-532. [Dragin, N. (2007). "Lekseme motivisane imenicom bog u omilijama svetog Nikolaja Srpskog (sinhronodijahroni pristup)“. Probleme de filologie slavă 15: 521-532.]

Драгићевић, Р. (2010). Лексикологија српског језика. Београд: Завод за уџбенике. [Dragićević, R. (22010). Leksikologija srpskog jezika. Beograd: Zavod za udžbenike.]

Ђорђевић, С., Шћепановић, М. (1996). Вукове народне пословице с регистром кључних речи. Београд: Нолит. [Đorđević, S., Šćepanović, M. (1996). Vukove narodne poslovice s registrom ključnih reči. Beograd: Nolit.]

Сикимић, Б. (1996). Етимологија и мале фолклорне форме. Београд: Институт за српски језик САНУ. [Sikimić, В. (1996). Etimologija i male folklorne forme. Beograd: Institut za srpski jezik SANU.]

Skok, P. (1971-1974). Etimologijski rječnik hrvatskoga ili srpskoga jezika, I-IV. Zagreb: Jugoslavenska akademija znanosti i umjetnosti. 
Valentina Ilić

University of Belgrade

Faculty of Philology - Department of Serbian language with South Slavic languages

Belgrade

vli1@ymail.com

\section{METHODOLOGICAL APPROACH TO ETYMOLOGY IN TEACHING LINGUISTIC ELECTIVE COURSE IN A HIGH SCHOOL}

\section{Summary}

This paper represents a methodological model based on three lessons dedicated to the linguistic elective course for the third year of high school in which the basic postulates of etymological science are discussed. The importance of these lessons is reflected in the fact that the etymology is insufficiently lectured even at the basic studies of the Serbian language. Therefore, this papers tends to offer high school teachers possible solutions of how to introduce this scientific discipline to talented students. At the first class students remeber the concepts of the language relationship and language families, and then learn about the genesis, development and methods of etymological science. The examples, whose etymology is presented at the second and third class, are drawn from the Serbian folk proverbs: the two most frequent nouns that appear in them are analysed in detail God and the house. Students learn about etymological dictionaries and practise to use them. Through these lessons the correlation between students' previous lexicological knowledge and knowledge about a related scientific discipline is achieved. In this way students' horizons are expanded and their interest in the word origin is awoken. The communicative approach in teaching is applied in this paper and the correlation between language and folk literature is achieved. Also, in this way students are highly motivated to spread and accumulate their general knowledge.

Key words: etymology, language relationship, word origin, folk proverbs, Serbian language teaching.

Примљено: 28. 3. 2016.

Прихваћено: 5. 5. 2016. 